$\xi=-1$

\title{
Behavior and strength of reinforced reactive powder concrete beams under impact loadings
}

\author{
Ibtihal Fadhil $^{1}$ *, Assist. Prof. Eyad K. Sayhood ${ }^{1}$, Assist. Prof. Nisreen Salih ${ }^{1}$ \\ ${ }^{1}$ Building and Construction Engineering Department, University of Technology / Baghdad \\ *Corresponding author E-mail:
}

\begin{abstract}
Reactive powder concrete is a new concrete that has been used in recent years because of many advantages. The use of reactive powder concrete in structural elements such as beams provides higher compressive strength, higher modulus of elasticity, durable concrete and increasing the concrete ductility, so that the concrete has high resistance against tensile stress. The experimental tests of the reinforced concrete beams under the effects of impact loadings are investigated in this paper. The parameters being adopted in present paper are steel fiber of $(1,1.5$ and $2 \%)$ by volume, dropped mass and height of drop. The reinforced concrete specimens were tested under impact load by one strike only. The test results indicate that the impact force increased when the compressive strength of concrete increased that when the steel fiber ratio becomes more and the deflection has become less.
\end{abstract}

Keywords: Impact Loading; Reactive Powder; Reinforced Concrete Beams; Experimental Test.

\section{Introduction}

The use of reactive powder concrete (RPC) is mainly to increase the compressive strength of concrete in absence of gravel and presence of silica fume and steel fiber with super plasticizer to reduce the water cement ratio and to increase the concrete workability. Many researchers have investigated the mechanical properties of reactive powder concrete such as compressive strength, tensile strength, flexural and modulus of elasticity. The reactive powder concrete (RPC) can be classified as cementious composite materials that contain material being mixed with each other and behaved as unity with excellent physical properties for strength and ductility. Impact analysis is very important and has many applications in structural engineering. The effects of impact force or acceleration usually have a greater and more effect than a lower force applied over a proportionally longer period. The effect depends critically on the relative velocity of the bodies to one another. The effects of impact loading are classified as local and flexural. The local effects of impact loading are penetration, scabbing, cracks and perforation. The flexural effects are deflection, energy losses, shear failure and reduced in moment capacity. The overall effects of the impact loading specially in case of high velocity with low mass such as missile cause distortion of the building when hit by this type of loading. Load - time curve for impact analysis as theoretical approach adopted by many researchers is assumed as triangular, rectangular or constant in additional to sine shape. There are underneath some researchers examined on the performance and behavior of structural elements under the effect of impact loading. In 2010, Samer P. Y. H [1] examined the behavior of (RPC) beams in pure bending in addition to the flexural and compressive strength. In 2013, Dhia B. G [2], studied reactive powder concrete (RPC) beams in both experimental and theoretical exertion. In 2013, Mohammed H. M [3] investigated and tested (RPC) and normal weight concrete beams. In 2013, Murtada A. I [4] carried out experimental and theoretical efforts to study the
(RPC) of hybrid beams made from reactive powder concrete under the effects of flexural loading. In 2014, Karrar I. Y [5] investigated the effects of steel fibers and silica fume on the properties of (RPC) beams. In 2014, Yahyia M. H [6] looked out on the behavior and strength of (RPC) reinforced concrete beams in both experimental and theoretical approaches. In 2014, M.M. Hossain et al [7] explored the crack and spallation of RC beams due to impact loading. In 2014, Iana I. R. D. et al. [8], tested reinforced concrete beams with compressive strength of (23 MPa) under affect loading in presence of steel fibers as additive material mixed with concrete. In 2014, I.K .Khan [9], investigated the reinforced concrete beams subjected to point impact loading. In 2015, Tingbian Z. et al. [10] investigated the Failure behavior of reinforced concrete beams under high impact load. In 2015, Shahariar F. H [11] studied the performance of the structural members under impact loading using finite elements approach.

In present paper, the behavior and strength of reinforced reactive powder concrete beams under impact loadings are investigated with different parameters such as the dropped mass, height of dropped and the percentages of steel fiber in additional to presence of cover steel plate at the top face of specimens.

\section{Materials}

Many parameters are adopted here such as silica fume with (12, 15,20 and $25 \%$ ) ratios, steel fiber mixed with concrete with ratios of $(1,1.5$ and $2 \%)$ by volume and water to cement ratio of $(0.20$ and 0.22 ), so that the compressive strength of concrete is changed based on the percentages of silica fume and steel fiber. Ordinary Portland cement (OPC) is used; type of fine aggregate is classified as very fine sand because the maximum size is $0.15 \mathrm{~mm}$. Ordinary tap water is used which is clean and free from injurious amounts of oils, acids, alkalis, salts and organic materials. The Sika Company produces the used silica fume. The used short steel fiber is supplied from Sika Company also. 


\section{Testing program}

The reinforced concrete specimen's details configuration and layout are shown in Figure (1). Nine reinforced concrete beams were tested under impact loading, the specimens are marked and listed in Table (1).

The instrumentations are used to measure the deflections for each stepped time by laser sensor. Load cell with capacity of $(100 \mathrm{KN})$ records the applied load that has been developed by the dropped mass. The velocity measurement is utilized for the dropped mass at the time of striking the top face of the specimens.

The tests have been conducted in the laboratory of University of Technology, Baghdad-Iraq. All specimens are tested by adopting the same procedure under impact loading by dropping steel mass that was released by gravity without any external force. The specimens were placed in their position in the testing frame with the finished face up. The falling mass was then dropped once and the deflection was recorded.. The dimensions of the testing frame were designed to allow observing the specimens from the bottom surface to show developing failure during testing. The reinforced concrete specimen was placed accurately in the middle of the testing machine. The tube of a circular section represents the vertical guide for the falling mass to ensure mid-span impact. Steel balls with masses of $(25,30$ and $35 \mathrm{~kg})$ were used in tests, the falling mass and load cell are shown in figure (2)

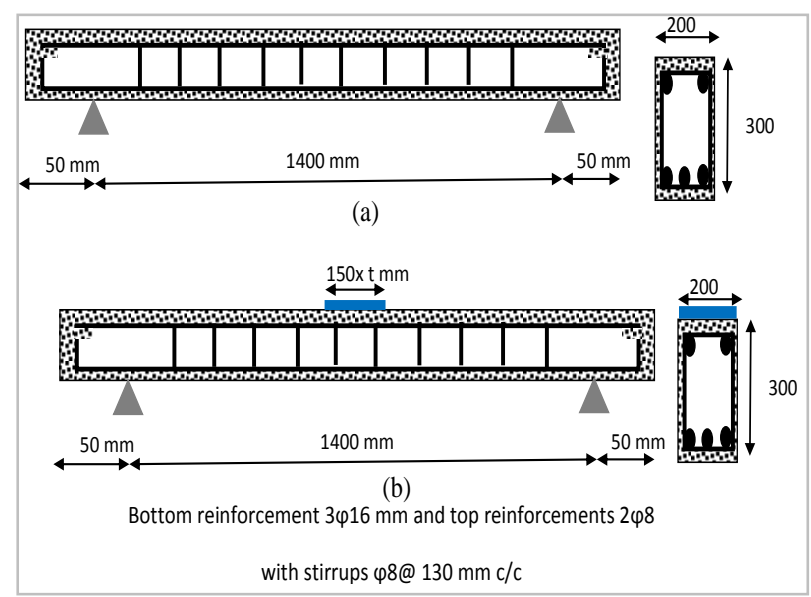

Fig. 1: Specimen Layout and Details A) Beam without Steel Plate at Impact Zone B) Beam with Steel Plate at Impact Zone.

\begin{tabular}{|c|c|c|c|c|c|c|c|}
\hline Group & $\begin{array}{c}\text { Specimen } \\
\text { mark }\end{array}$ & $\begin{array}{c}\text { Mass } \\
(\mathrm{kg})\end{array}$ & $\begin{array}{l}\text { Height } \\
(\mathrm{m})\end{array}$ & $\begin{array}{c}\text { Compressive } \\
\text { strength } \\
\text { (MPa) }\end{array}$ & $\% \mathrm{~V}_{\mathrm{f}}$ & $\begin{array}{c}\text { Zone } \\
\text { Characterize }\end{array}$ & $\begin{array}{c}\text { Parameter } \\
\text { studied }\end{array}$ \\
\hline G1 & G1B1 & 25 & 2 & 82.30 & 1 & Concrete & $\begin{array}{c}\text { Control } \\
\text { Beam }\end{array}$ \\
\hline \multirow{2}{*}{ G2 } & G2B1 & 30 & 2 & 82.30 & 1 & \multirow{2}{*}{ Concrete } & \multirow{2}{*}{$\begin{array}{l}\text { Falling } \\
\text { Mass }\end{array}$} \\
\hline & G2B2 & 35 & 2 & 82.30 & 1 & & \\
\hline \multirow{2}{*}{ G3 } & G3B1 & 25 & 1.4 & 82.30 & 1 & \multirow{2}{*}{ Concrete } & \multirow{2}{*}{$\begin{array}{c}\text { Height of } \\
\text { Dropped } \\
\text { Mass }\end{array}$} \\
\hline & G3B2 & 25 & 1.7 & 82.30 & 1 & & \\
\hline \multirow[b]{2}{*}{ G4 } & G4B1 & 25 & 2 & 82.30 & 1 & $\begin{array}{l}\text { Plate with } \\
1 \mathrm{~mm} \text { thick }\end{array}$ & \multirow[b]{2}{*}{ Steel Cover } \\
\hline & G4B2 & 25 & 2 & 82.30 & 1 & $\begin{array}{c}\text { Plate with } \\
1.4 \mathrm{~mm} \\
\text { thick }\end{array}$ & \\
\hline \multirow{2}{*}{ G5 } & G5B 1 & 25 & 2 & 94.03 & 1.5 & \multirow{2}{*}{ Concrete } & \multirow{2}{*}{$\begin{array}{c}\text { Percentage } \\
\text { of Steel } \\
\text { Fiber }\end{array}$} \\
\hline & G5B2 & 25 & 2 & 101.93 & 2 & & \\
\hline
\end{tabular}

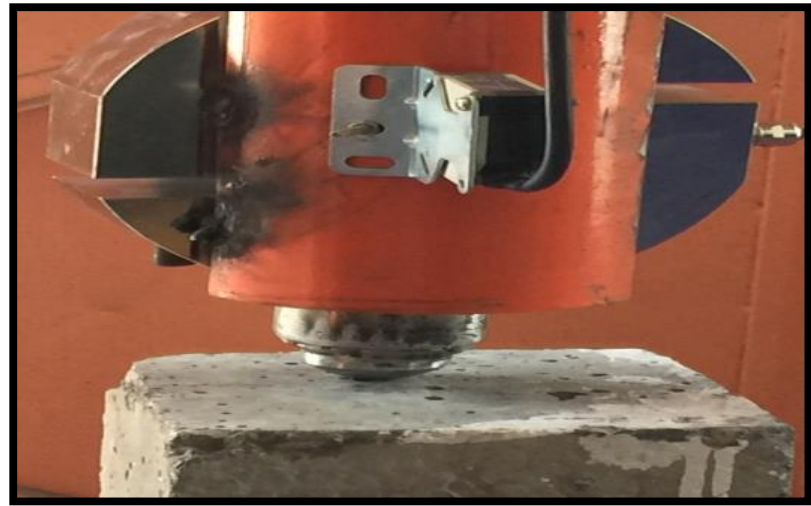

Fig. 2: The Configuration of Load Cell with Dropped Masses.

The testing rig as shown in Figure (3) consists of main parts as follow:-

1) Strong and heavy steel frame to hold rigidly during impact loading. The dimensions of the testing frame were designed to allow observing the specimens from the bottom surface to observe the developing failure during testing. The reinforced concrete specimen was placed accurately in the middle of the testing rig.

2) Tube of a circular section: was used as a vertical guide for the falling mass to ensure mid-span impact.

3) Steel balls with masses of $(25,30$ and $35 \mathrm{~kg})$.

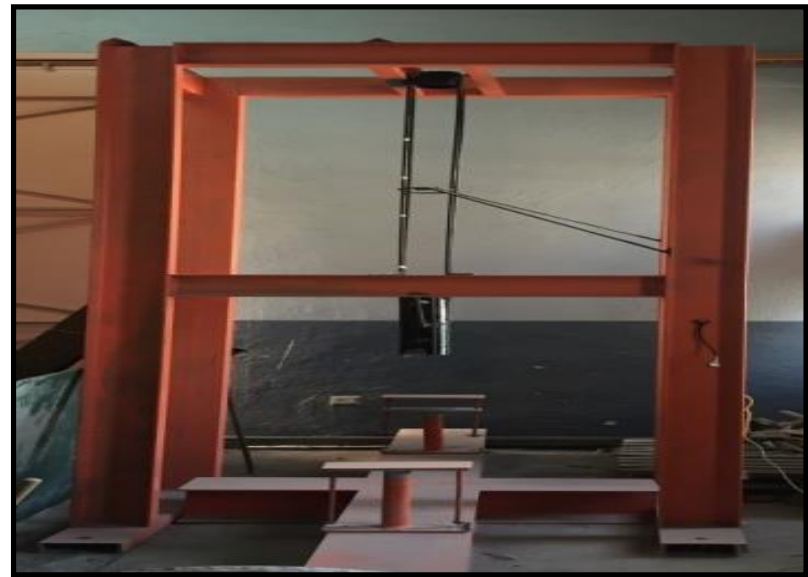

Fig. 3: Testing Frame Steel Setup.

The instrumentations used to measure the mid span deflections for each stepped time by laser sensor are shown in Figure (4). Load cell with capacity of $(100 \mathrm{kN})$ was used to record the applied load that was developed by the dropped mass as shown in Figure (5).

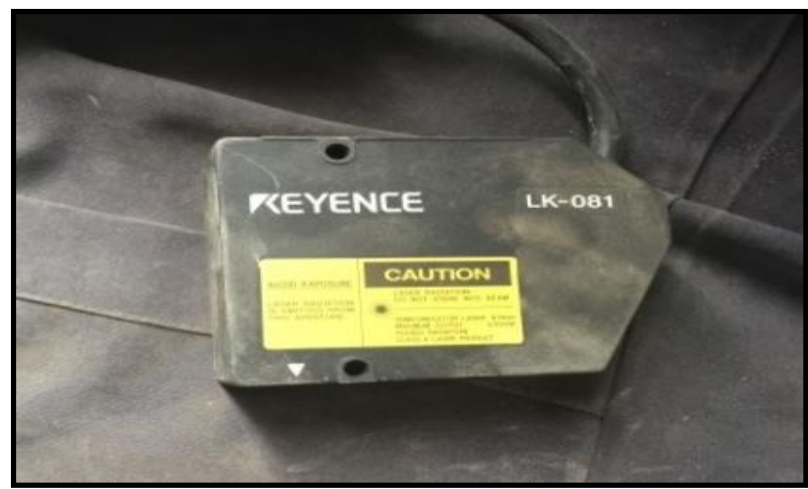

Fig. 4: Laser Senior to Measure the Deflections. 


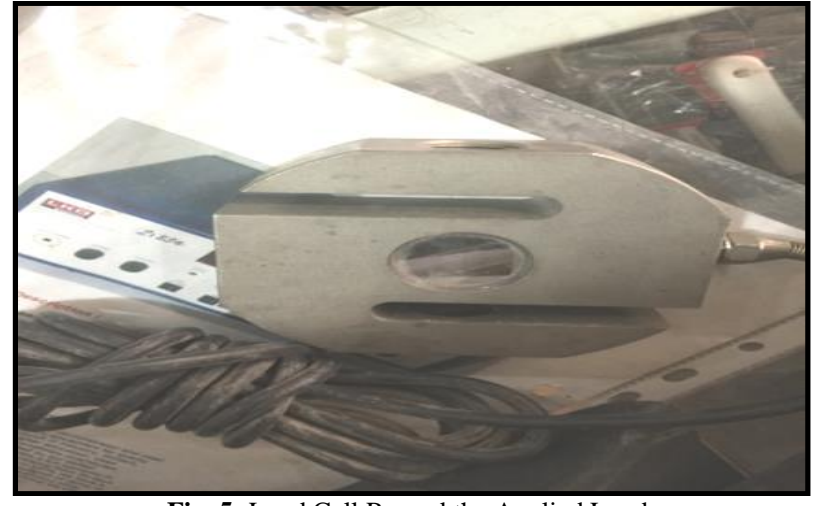

Fig. 5: Load Cell Record the Applied Load.

The velocity measurement for the dropped mass at the time of striked the top face of the specimens is shown in Figure (6) and the accelerometer is shown in Figure (7).

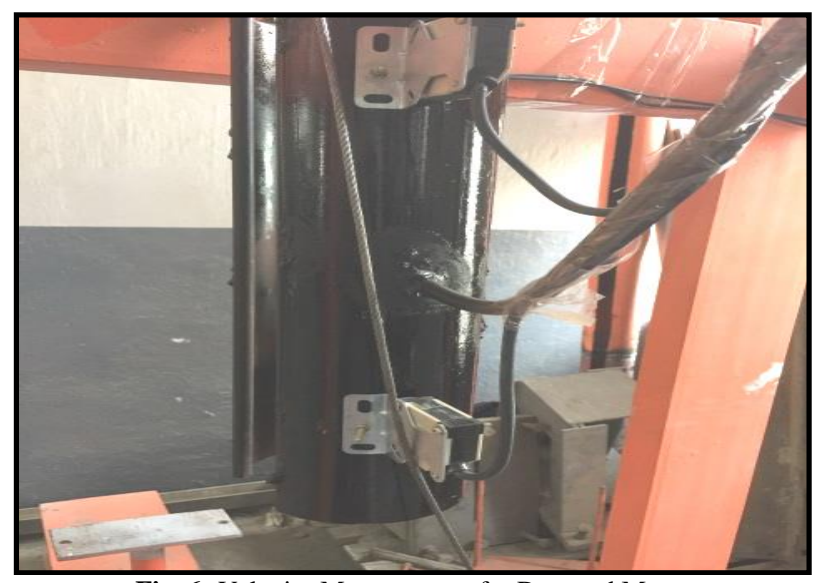

Fig. 6: Velocity Measurement for Dropped Mass.

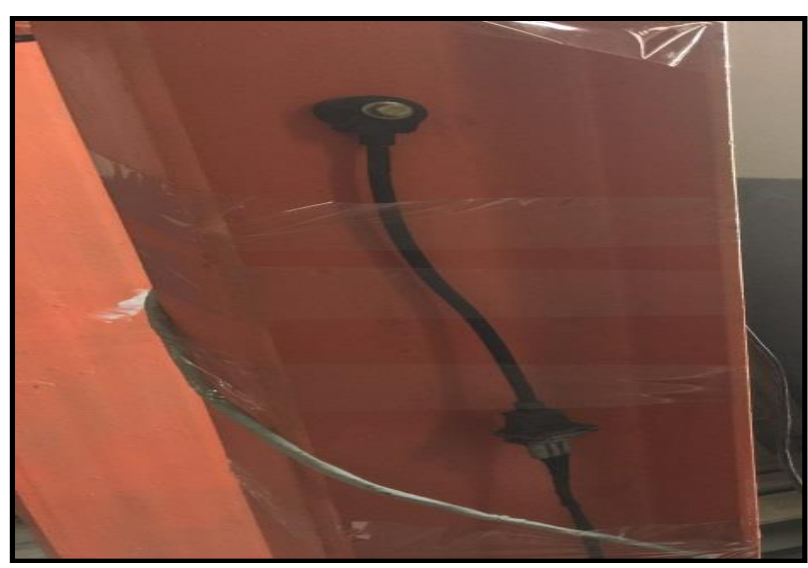

Fig. 7: Accelerometer Measurement for Dropped Mass.

The specimens are placed at the center of the steel frame that was designed for free mass fall as shown with specimen's setup in Figure (8).
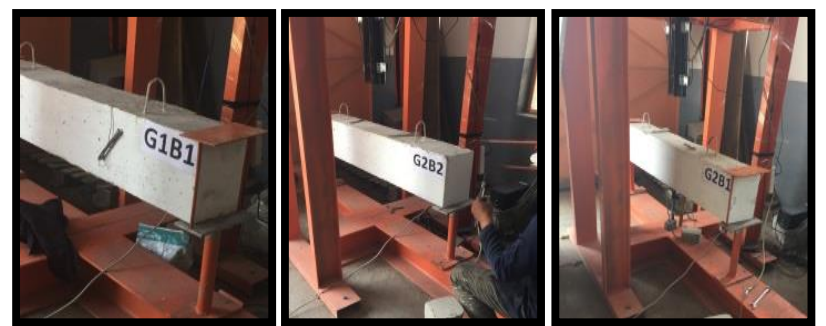

Fig. 8: Test of Specimens with the Devices Setup.

\section{Results}

Three different masses that mentioned in Table (1) were dropped freely and stroked the reinforced concrete beams with three different percentages of steel fibers. Figure (9) shows the penetration hole that was developed at the top face of the specimens due to the dropped masses. Figure (10) shows the manual methodology that was adopted to measure the depth and the diameter of the penetration hole which was checked by laser device later. Figures (11) to (18) represent the full behavior of the load-time and deflectiontime for all specimens. The general behavior of load-time curve is triangular in shape and the maximum impact force depends on the concrete type and mass. The deflection-time curve shows the same behavior for all specimens depending on the dropped mass and the compressive strength of concrete. Table (2) lists the impact force and maximum deflection at specified times for specimens.
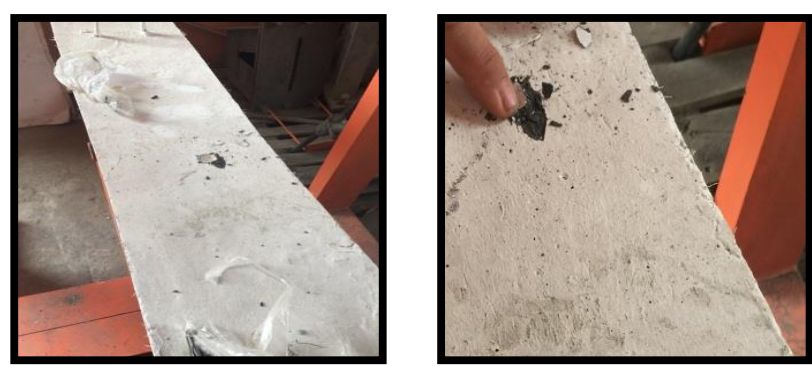

Fig. 9: Penetration Hole at the Top Face of the Specimens.
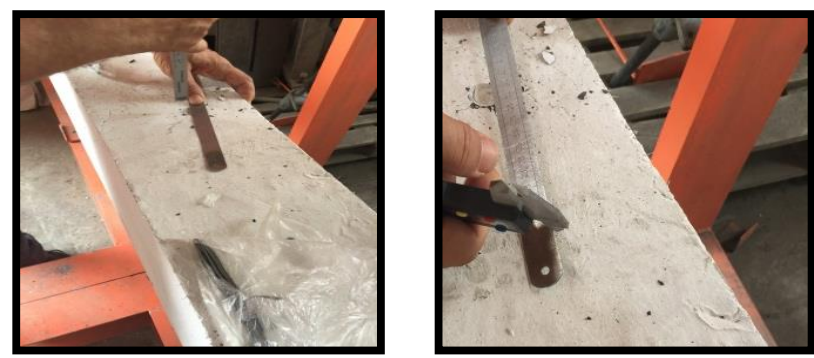

Fig. 10: Manual Methodology to Measure the Depth and the Diameter of the Penetration Hole.

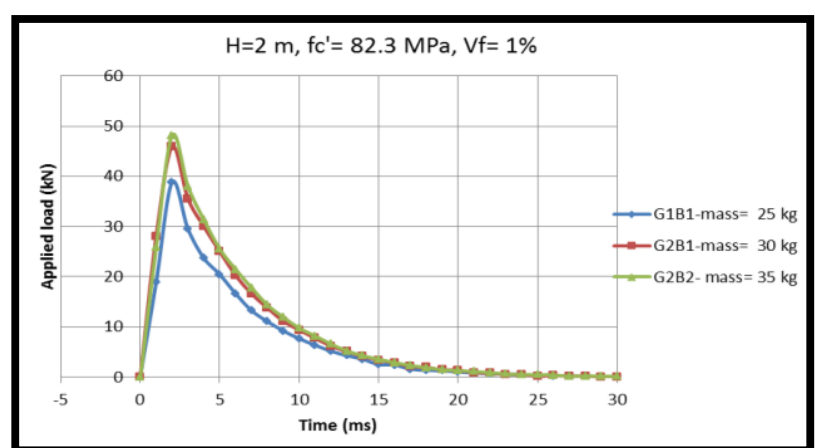

Fig. 11: Load-Time Behavior for G1B1, G2B1 and G2B2 Specimens.

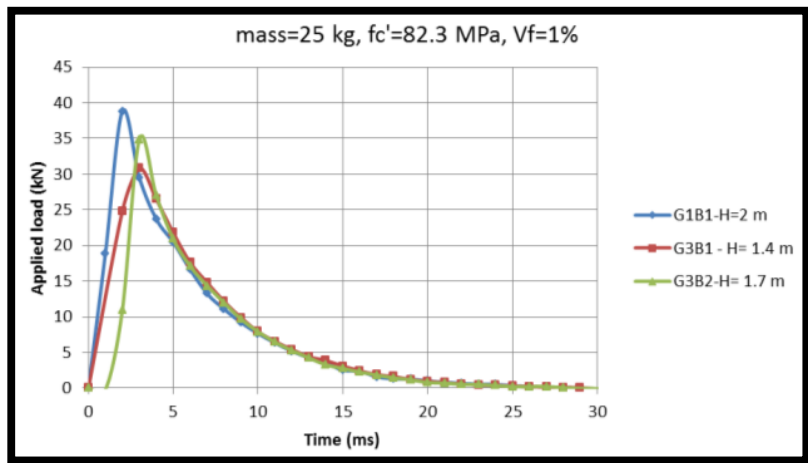

Fig. 12: Load-Time Behavior for G1B1, G3B1 and G3B2 Specimens. 


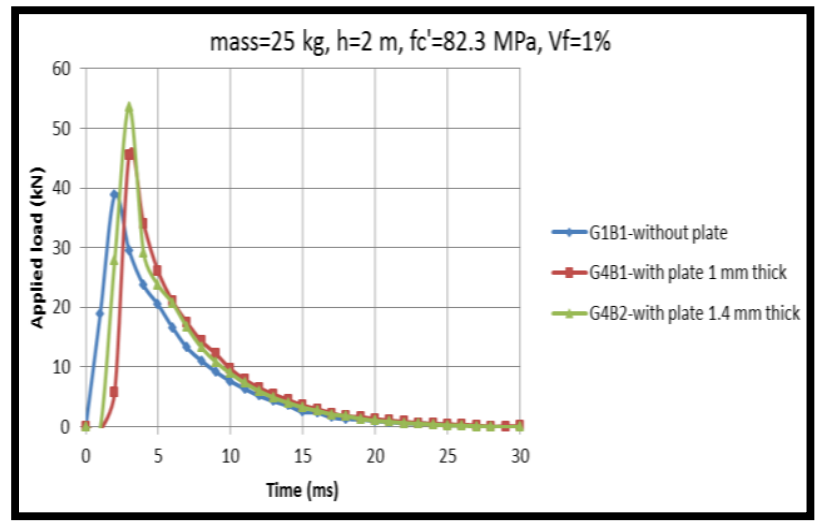

Fig. 13: Load-Time Behavior for G1B1, G4B1 and G4B2 Specimens

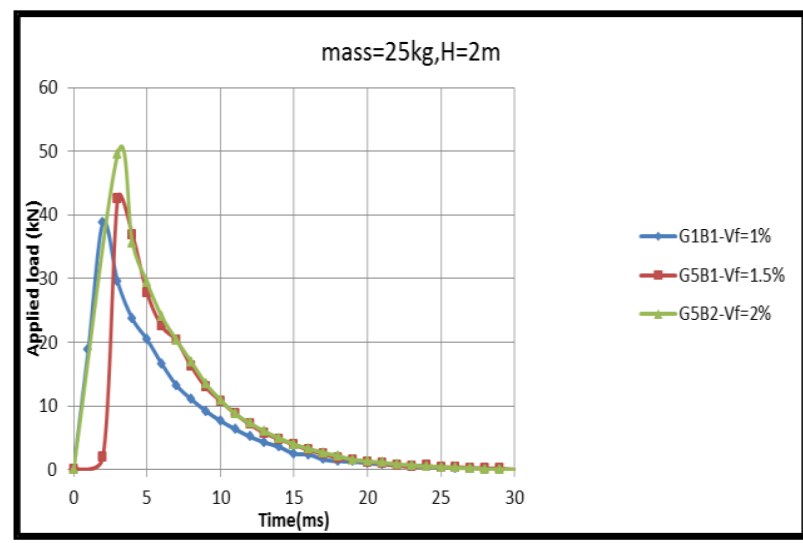

Fig. 14: Load-Time Behavior for G1B1, G5B1 and G5B2 Specimens.

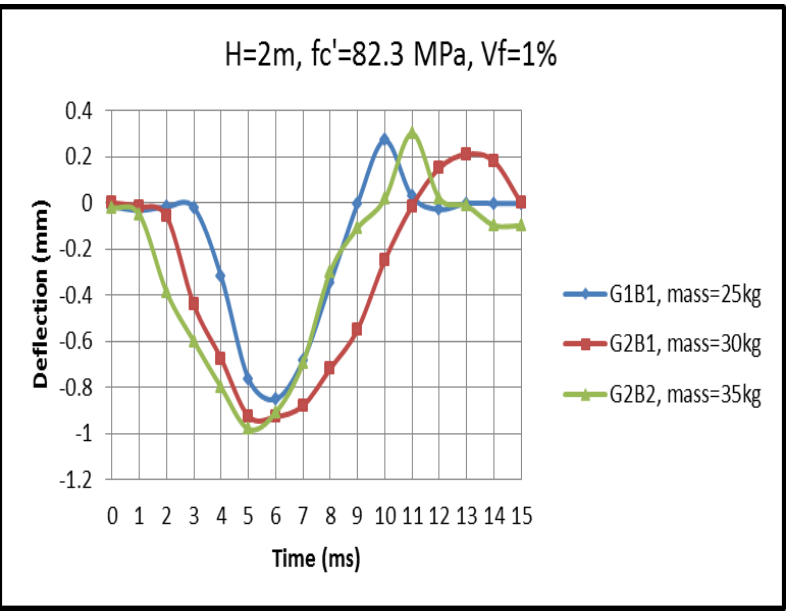

Fig. 15: Deflection-Time Behavior for G1B1, G2B1 and G2B2 Specimens.

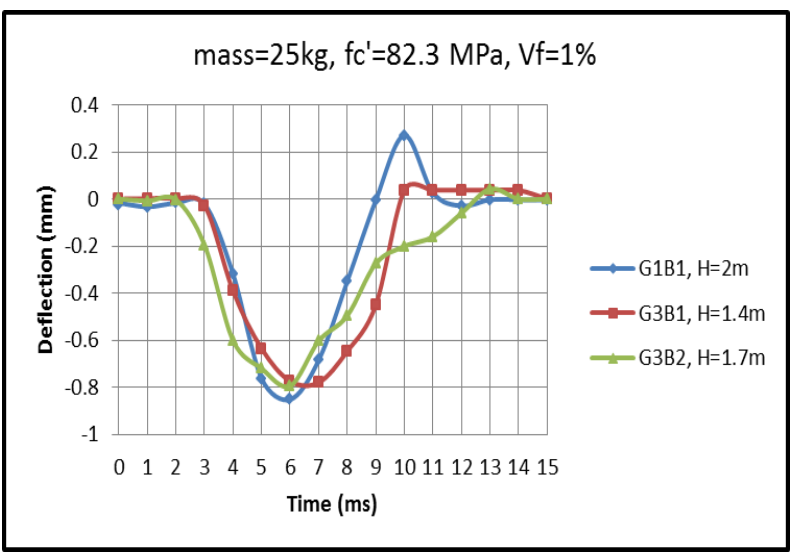

Fig. 16: Deflection -Time Behavior for G1B1, G3B1 and G3B2 Specimens.

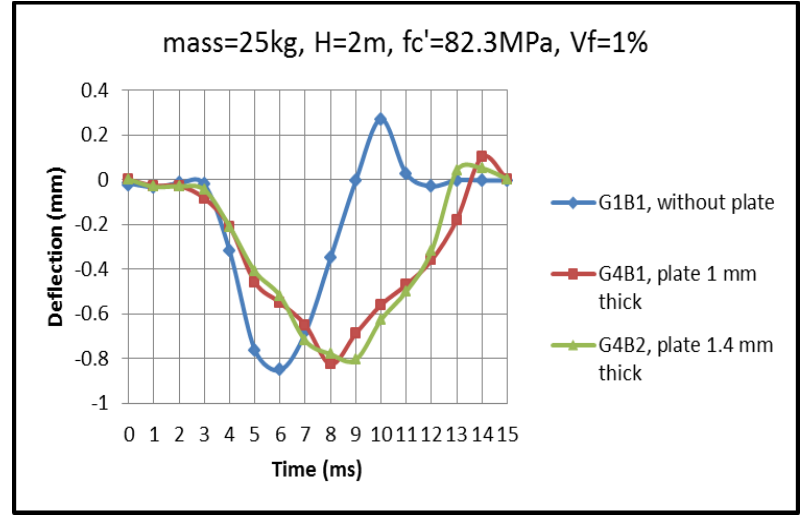

Fig. 17: Deflection-Time Behavior for G1B1, G4B1 and G4B2 Specimens.

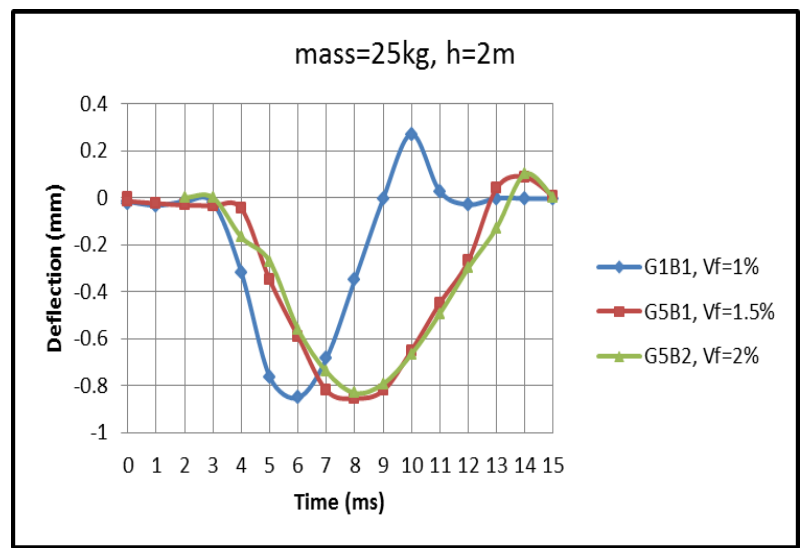

Fig. 18: Deflection -Time Behavior for G1B1, G5B1 and G5B2 Specimens.

\begin{tabular}{|c|c|c|c|c|c|c|c|c|}
\hline Group & $\begin{array}{c}\text { Specimen } \\
\text { mark }\end{array}$ & $\begin{array}{c}\text { Maximum } \\
\text { impact } \\
\text { force }(\mathrm{kN})\end{array}$ & $\begin{array}{l}\text { Time } \\
\text { (ms) }\end{array}$ & $\begin{array}{l}\% \text { of maximum } \\
\text { impact load } \\
\text { refer to control } \\
\text { specimen }\end{array}$ & $\begin{array}{c}\text { Maximum } \\
\text { deflection } \\
(\mathrm{mm})\end{array}$ & $\begin{array}{l}\text { Time } \\
(\mathrm{ms})\end{array}$ & $\begin{array}{l}\% \text { of maximum } \\
\text { deflection refer } \\
\text { to control } \\
\text { specimen }\end{array}$ & $\begin{array}{l}\text { Penetration } \\
\text { depth } \\
(\mathrm{mm})\end{array}$ \\
\hline G1 & G1B1 & 38.80 & 2 & $\begin{array}{c}\text { control } \\
\text { specimen }\end{array}$ & 0.85 & 6 & $\begin{array}{c}\text { control } \\
\text { specimen }\end{array}$ & 3.11 \\
\hline \multirow{2}{*}{ G2 } & G2B1 & 45.87 & 2 & 18.00 & 0.93 & 6 & 9.53 & 3.27 \\
\hline & G2B2 & 48.15 & 2 & 24.09 & 0.98 & 5 & 17.71 & 4.51 \\
\hline \multirow{2}{*}{ G3 } & G3B1 & 30.81 & 3 & -20.59 & 0.72 & 7 & -10.31 & 2.77 \\
\hline & G3B2 & 34.85 & 3 & -10.18 & 0.78 & 7 & $\begin{array}{l}-8.07 \\
\end{array}$ & 3.06 \\
\hline \multirow{2}{*}{ G4 } & G4B1 & 45.50 & 3 & 17.26 & 0.82 & 8 & -2.58 & 2.482 \\
\hline & G4B2 & 53.50 & 3 & 37.88 & 0.81 & 9 & -4.49 & 1.57 \\
\hline \multirow{2}{*}{ G5 } & G5B1 & 42.50 & 3 & 9.53 & 0.85 & 8 & 0.00 & 2.84 \\
\hline & G5B2 & 49.50 & 3 & 27.57 & 0.83 & 8 & -2.58 & 2.11 \\
\hline
\end{tabular}

\section{Discussions}

The momentum that has been developed due to the dropped mass relays on the height of the dropped mass and the mass itself because of the stroked velocity depends on the height, so that when the height increases the velocity increases and so on the momentum increases. Also, when the mass increases, the momentum increased. As the momentum increases, the penetration depth at the top face and deflection at the bottom face of specimen increase. At the end of the first phase of the central impact, the kinetic energy of both masses changes partially into the common kinetic energy of both masses as well as transforms partially into deformation energy.

The presence of cover steel plate reduces the penetration and deflection because of the plate absorbs the energy that has been developed due to the dropped mass so that the effect of mass on the top face of concrete becomes little which causes a reduction in penetration and deflection. Deformation energy is the sum of the energy absorbed by both bodies at the end of the first impact 
phase, taking into consideration the fact that the steel plate is much more rigid.

Table (2) lists the maximum impact force that has been developed due to the applied masses with different heights of dropping at the top face of the beam specimens with special case of presence cover steel plates. The developed impact force increases as the dropped mass and height increase because of the kinetic energy increases and leads to increase the penetration depths and deflections. The presence of cover steel plate at the top face of the beams has worked as composite structure so that the equivalent moment of inertia and the modulus of elasticity increase and these lead to decrease the deflections and increase the resistance strength capacity of the beams. The comparisons between all impact forces with percentages increasing or decreasing are listed in Table (2).

\section{Conclusions}

Based on the test results, the following points are observed and concluded:

1) The impact force increases as the compressive strength increases (due to increase in steel fiber ratio) because of the concrete becomes stiffer and the flexural stiffness increases.

2) The deflection decreases as the compressive strength increases because of the increase in modulus of elasticity (increase in flexural stiffness).

3) The time required to reach the maximum impact force increases as the dropped mass becomes less and when the compressive strength of concrete becomes less (less steel fiber ratio).

4) The penetration depth decreases as the mass decreased because of less kinetic energy.

5) The penetrations depth decreased as the steel fiber ratio increases because of the increase in compressive strength.

\section{References}

[1] Samer P. Y. H., "Behavior of reactive powder concrete beams in bending", Ph.D. Thesis, University of Technology, (2010).

[2] Dhia B. G., "Shear-transfer strength and behavior of reactive powder concrete", Ph.D. Thesis, Al-Mustansiriya University, (2013).

[3] Mohammed H. M., "Flexural behavior of hybrid beams containing reactive powder concrete and conventional concrete", Ph.D. Thesis, Al-Mustansiriya University, (2013).

[4] Murtada A. I., "Flexural behavior of reactive powder concrete tee beams", Ph.D. Thesis, Al-Mustansiriya University, (2013).

[5] Karrar I. Y., "Drying shrinkage and cracking of reactive powder reinforced concrete under loading", MSc Thesis, Al-Mustansiriya University, (2014).

[6] Yahyia M. H., "Behavior of reinforced concrete I - beams containing reactive powder concrete", Ph.D. Thesis, Al-Mustansiriya University, (2014)

[7] M.M. Hossain et al, "Crack chronology of reinforced concrete beam under impact loading", Middle-East Journal of Scientific Research 21 (9), pp. 1663-1669, (2014).

[8] Iana I. R. D. et al, "RC beams with steel fibers under impact loads", Acta Scientiarum. Technology, Maringá, v. 36, n. 1, pp. 23-31, (2014).

[9] I.K. Khan, "Performance of reinforced concrete beam under point impact loading", American International Journal of Research in Science, Technology, Engineering \& Mathematics, pp. 146-150, (2014).

[10] Tingbian Z. et al, " Failure behaviors of reinforced concrete beams subjected to high impact loading", Engineering Failure Analysis 56, 233-243

(2015) https://doi.org/10.1016/i.engfailanal.2015.02.006

[11] Shahariar F. H., "Numerical modeling of reinforced concrete members under impact load", MSc thesis, Bangladesh university of engineering and technology, Dhaka, Bangladesh, (2015). 